\title{
CONSILIUM
}

Berkala Kajian Konseling Dan Ilmu Keagamaan

Avalaible at http://jurnal.uinsu.ac.id/index.php/consilium

ISSN : 2338-0608 (Print) | ISSN : 2654-878X (Online)

\section{Penerapan Layanan Penguasaan Konten Untuk Mengembangkan Kreativitas Belajar Anak Berbakat}

\author{
Ita Lestari \\ Universitas Muhammadiyah Sumatera Utara, Indonesia. \\ Korespondensi: lestari23ita11@gmail.com
}

\begin{abstract}
Abstrak: Siswa kelas VIII di SMP Muhammadiyah 07 Medan memiliki kekurangan untuk mengembangkan kreativitas belajarnya dan juga sulit untuk membuat suatu konsep dari pembelajaran. Mereka susah untuk membuat ide kreativitasnya dengan berbagai bidang studi yang ada disekolah tersebut. Mereka bingung untuk membuat ide kreativitasnya agar terlihat catatan menjadi menarik. Permasalahan dari penelitian ini adalah tentang penerapan layanan penguasaan konten untuk mengembangkan kreativitas anak berbakat. Tujuan dari penelitian ini: Untuk mengetahui adanya penerapan layanan penguasaan konten untuk mengembangkan kreativitas belajar anak berbakat siswa kelas VIII SMP Muhammadiyah 07 Medan T.A 2019/2020. Adapun dalam penelitian ini ada enam siswa yaitu 3 siswa laki-laki dan 3 siswa perempuan kelas VIII. Jenis penelitian ini yaitu penelitian kualitatif Teknik pengumpulan data dilakukan dengan menggunakan observasi dan wawancara siswa-siswa yang bersangkutan. Dari hasil penelitian yang dapat diketahui bahwa penerapan layanan penguasaan konten untuk mengembangkan kreativitas belajar anak berbakat siswa kelas VIII SMP Muhammadiyah 07Tahun Ajaran 2019/2020. Sudah berjalan dengan baik dan sesuai rencana. Pada pelaksanaan layanan penguasaan konten 6 siswa yang mengalami kekurangan megembangkan kreativitas belajarnya dan setelah melakukan layanan sudah memiliki perubahan yang diharapkan dan pada pelaksanaan layanan penguasaan konten terjadi peningkatan sangat meningkat .
\end{abstract}

Kata Kunci: Layanan Penguasaan Konten, Kreatifitas, Belajar, Anaka Berbakat.

\section{PENDAHULUAN}

$\mathrm{P}$ endidikan adalah usaha sadar terencana untuk mewujudkan suasana dan proses pembelajaran agar peserta didik mempu dan aktif dalam mengembangkan potensi yang dimilikinya. Dengan adanya pendidikan ataupun timbul rasa pengetahuan dan pembahasan ilmu baik budi pekerti ataupun memotivasi diri agar lebih dalam aspek kehidupan bekelanjutannya. UU NO 20 Pasal 3 yaitu " Pendidikan Nasional berfungsi mengembangkan kemampuan dan membentuk watak serta peradaban bangsa yang martabat dalam rangka mencerdaskan kehidupan bangsa dan bertujuan untuk berkembangnya potensi yang dimiliki peserta didik dan agar menjadi seorang manusia yang memiliki rasa iman dan bertaqwa kepada Allah Yang Maha Esa, berahklak mulia, sehat jasmani dan rohani, berilmu, cakap, kreatif, mandiri, dan sebagai pencapaian kemandirian sehari-hari serta bertanggung jawab". 
Menurut Sukarti (2017:103) “ Kreativitas adalah sesuatu yang baru dalam kehidupan sehari-hari yang terkait dengan potensi istimewa selain itu menemukan hal-hal baru dan melihat adanya berbagai wawasan serta potensi yang diketahuinya dengan potensi yang dihasilkannya melalui pandangan baru terhadap kondisi dan situasi yang ada.

Pada dasarnya siswa yang kurang untuk mengembangkan kreativitas belajar adalah siswa yang kurang untuk mencoba kreativitas dan mengembangkannya atau membuat konsep belajar dari pemebelajaran yang sedang berlangsung. Atau

tidak bisa menggambarkan kreativitas belajar mereka didalam kelas dengan membuat sebuah karya-karya yang unik mengenai tentang pelajaran yang dipelajarin pada saat dikelas.

Berdasarkan observasi pengalaman magang sebelumnya maka dapat menjadi sebuah alasan yang sangat mendasari bagi peneliti untuk membahas pemasalahan di Kelas VIII A 07 Muhammadiyah Medan, mengenai kurangnya kemampuan untuk menemukan ide baru, sebagian siswa belum mendapatkan ide kreativitas belajarnya, kurangnya minat keberbakatannya.

Maka dengan Observasi yang telah terlihat Penelitian melaksanakan layanan penguasaan konten untuk mengembangkan kreativitas siswa berbakat yang bertujuan agar siswa pada saat pembelajaran banyak aktif untuk menunjukan ideide mereka dengan menggambarkan dan memasukan suatu catatan konsep pembelajaran kemudian dapat menyimpulkan hasil pembelajaran dari seorang guru bidang study. Dengan permasalahan yang ada peneliti penyelesaian permasalah dengan menggunakan layanan penguasaan konten. Menurut Prayitno, 2017: 96 "Layanan penguasaan konten merupakan bantuan kepada individu ( sendiri-sendiri ataupun dalam kelompok atau klasikal J untuk menguasai kemampuan atau kompetensi tertentu. Kemampuan atau kompetensi yang dipelajari itu merupakan satu unit konten yang didalamnya terkandung fakta dan data, konsep,proses, hukum dan aturan, nilai persepsi , afeksi, sikap dan tindakan yang terkait didalamnya".

Dengan melihat Fenomena yang ada pada masa sekarang ada bebrapa siswa yang kurang aktif untuk mengembangkan kreativitas belajar didalam pembelajaran dari seorang guru bidang study.Dengan melihat adanya siswa yang kurang mampu untuk mengembangkan kreativitas belajar penelitian akan menggunakan layanan penguasaan konten.

Berdasarkan latar belakang yang telah dijelaskan sebelumnya maka dapat menjadi alasan yang sangat mendasar bagi peneliti untuk membahas permasalahan tersebut dalam sebuah penelitian yang berjudul " Penerapan Layanan Penguasaan Konten Untuk Mengembangkan Kreativitas Belajar Anak Berbakat Kelas VIII di SMP Muhammadiyah 07 Medan Tahun Ajaran 2019/2020 ". 


\section{METODE PENELITIAN}

Pengumpulan data dapat dilakukan dalam berbagai setting berbagai sumber, dan berbagai cara. Bila dilihat dari setting-nya, data dapat dikumpulkan pada setting alamiah ( atural setting) dari sumber datanya, maka pengumpulan data dapat menggunakan sumber data yang langsung memberikan data kepada pengumpulan data, dan sumber sekunder merupakan sumber tidak langsung memberikan data kepada pengumpulan data, misalnya lewat orang lain atau lewat dokumen. Selanjutnya bila dilihat dari segi cara atau teknik pengumpulan data, maka teknik pengumpulan data dapat dilakukan dengan observasi,wawancara (Interview).

\section{HASIL PENELITIAN DAN PEMBAHASAN}

Penelitian ini dilaksanakan di SMP Muhammadiyah 07 Medan Tahun Ajaran 2019/2020. Hasil penelitian diperoleh melalui observasi yang bertujuan untuk melihat situasi yang ada pada saat melakukan riset,wawancara di lakukan terhadap siswa/siswi yang dijadikan sebagai objek penelitian yang sebanyak 6 siswa diantaranya 3 siswa dan 3 siswi dan selain diberikan terhadap peserta didik wawacara juga diberikan kepada seorang Guru BK sebagai bertujuan untuk membantu memperoleh data yang sesuai, setelah wawancara dillakukan selanjutnya yaitu dokumentasi yang dilakukan saya sendiri sebagai bukti bahwa saya sedang melaksanakan riset yang sesungguhnya. Dari ketiga teknik penggumpulan data yang digunakan bertujuan untuk memperoleh data tentang penerapan layanan penguasaan konten untuk mengembangkan kreativitas anak berbakat hasil pengumpulan data di laksanakan demi memperoleh hasil agar dapat dijadikan analisis awal. Pada penelitian ini jadwal yang akan dilaksanakan sebelumnya telah disetujui oleh guru wali kelas dan guru bimbingan dan konseling. Dalam penelitian ini dibutuhkan waktu 1 kali pertemuan dengan waktu maksimal 45 menit, agar supaya hal ini tidak mengganggu proses pembelajaran siswa didalam kelas.

Dalam penelitian ini terdapat tiga pengamatan diantaranya diatas pertanyaan yaitu melalui wawancara, penelitian dengan pengamatan secara langsung dilapangan (observasi) dan sesi foto sebagai bukti dalam penelitian yang dilaksanakan (dokumentasi) .

\section{Pelaksanaan Layanan Penguasaan Konten}

Pendidikan sangat membutuhkan suatu Unit pelayanan Bimbingan dan Konseling disetiap sekolah untuk memecahkan permasalahan atau konflik, bukan hanya sebuah konfil tetapi juga dapat dijadikan sebagai pengukuran potensi dari setiap individu masing-masing secara individual atau kelompok. Bimbingan dan konseling adalah sebuah bantuan dari seorang konselor (Guru BK) kepada klien ( Siswa).Bimbingan dan konseling bukan hanya diberikan terhadap siswa tetapi dapat diberikan kepada semua manusia hidup dari usia anak-anak sampai usia lanjut. Karena manusia hidup memiliki konflik atau permasalahan hidup masingmasing dan berbeda. Sebab itu pelaksanaan bimbingan dan konseling di SMP Muhammadiyah 07 Medan sudah diberikan suatu layanan Penguasaan Konten.

Pada proses penelitian pertama yaitu suatu wawancara yang telah disetujui adalah dengan Bapak Reza selaku Guru Bimbingan dan Konseling disekolah SMP 
Muhammadiyah 07 Medan dengan uapaya mengenai layanan bimbingan dan konseling disekolah SMP Muhammadiyah 07 Medan. Pelaksanaan dilaksanakan dengan efektif dan efesien, tetapi tanpa disengaja masih ada menjumpai hambatan dalam layanan tersebut.

Layanan penguasaan konten pada pelaksanaan seorang peneliti melakukan pemahaman tentang belajar pada seorang siswa, mengerti permasalahan yang dihadapi siswa tentang belajar. Pada pelaksanaan layanan penguasaan konten sedang berlangsung peneliti memberikan saran serta arahan terhadap siswa dengan bertujuan agar mampu memahami permasalahan dapat menyelesaikan dengan mengikut arahan atau jalan keluar dari seorang konselor. Setelah seorang konselor memberi suatu pemahaman tentang konseling serta asas yang diberikan kepada kliennya.

\section{Siswa kurang mampu menemukan konsep baru}

Menemukan konsep baru yaitu menemukan suatu pemikiran baru agar dapat menemukan semangat untuk belajar kembali dengan perubahan ataupun perkembangan yang pada situasi yang sama namun semuanya tampak ada yang berbeda dari sebelumnya. Perbedaan yang ia dapatkan akan menjadi suatu suatu kerativitas yang tampak pada diri siswa. Kreativitas tersebut yaitu siswa dapat mengembangkan ide-ide yang sangat kreatif dengan menggambar suatu hal yang ia suka dan dapat memukan kalimat-kaliamat yang singkat tanpa banyak kata lain yang ia tuliskan. Karena kaliamat singkat akan mudah dipahami dengan penguasanya sendiri daripada mendapatkan kata atau kaliamat didalam buku cetak tersebut. Hal ini dapat terlihat dan masih banyak di alami oleh siswa/siswi di berbagai sekolah atau lembaga pendidikan baik tingkat SD,SM dan SMA.

Penelitian melakukan wawancara kepada guru bimbingan konseling yang telah bekerja sama dengan wali kelas sekaligus guru bidang studi dikelas VIII A mengenai siswa yang kurang mampu menemukan peta konsep terutamadi kelas VIII A SMP Muhammadiyah 07 Medan. (Melalui wawancara dengan Guru BK) .

Dari hasil pertanyaan atau wawancara yang kurang dalam mengembangkan kreativitas di SMP Muhammadiyah 07 medan pak Reza selaku Guru Bimbingan dan Konseling yang selalu bekerja sama dengan guru wali kelas VIII 2 mengenai hasil belajar dan kreativitas belajarnya ada beberapa siswa yang bermasalah dalam mengembangakan kreativitas belajar. Pada proses belajar mengajar tidak memperhatikan dan mendengarkan guru mengajar, mencatat sesuka hatinya, dan apabila siswa disuruh meringkas semuanya dicacat sampai habis tidak mengetahui pokok-pokok konsep yang ada dan memnjadi malas untuk membacanya ulang kembali karena terlalu banyak yang siswa tuliskan. Hal ini sehingga siswa tidak mampu mengembangakn kreativitasnya. Terdapat 6 siswa dan siswi yang mengalami kesulitan dalam mengembangkan kreativitas belajarnya didalam kelas.

Menurut hasil wawancara diatas yaitu masih sebagian siswa yang kurang mampu memngembangkan kreativitas belajar. Karena hal ini didukung oleh observasi yang dilakukan oleh peneliti disekolah. Kegiatan penelitian ini dilakukan bukan hanya kepada Guru Bk saja tetapi juga menjalinkan kerja sama dengan wali kelas yang memantau seorang siswa SMP Muhammadiyah 07 medan setiap saat dikelas pada saat pembelajaran sedang berlangsung ataupun pelajaran 
yang lain terjalin dengan aktif sehingga dapat mengatasi permasalahan yang mudah diselesaikan dngan guru BK.

\section{Penerapan layanan penguasaan konten untuk mengembangkan kreativitas belajar anak berbakat}

Layanan penguasaan konten yaitu bantua dari konselor kepada klien secara individual atau kelompok untuk menguasai kemampuan atau kompetensi tertentu. Kemampuan atau kompetensi yang dipelajari itu merupakan suatu unit konten yang didalamnya terkandung fakta dan data, konsep, proses, hukum dan aturan, nilai persepsi, afeksi, sikap dan tindakan yang terkait didalamnya. Kreativitas belajar adalah sesuatu yang baru dalam kehidupan sehari-hari yang terkait dengan potensi istimewa selain itu menemukan hal-hal baru dan melihat adanya berbagai wawasan serta potensi yang diketahuhinya melalui pandangan baru terhadap kondisi dan situasi yang ada. Anak berbakat adalah anak yang dilahirkan oleh seseorang yang berbakat dan memiliki sebuah ide yang sangat unik serta talenta yang dimiliki dengan mennjukkan keluarbiasaan yang khusus sifatnya.

Berikut adalah penerapan layanan penguasaan konten untuk mengembangkan kreativitas belajar aak berbakat siswa kelas VIII-2 SMP Muhammadiyah 07 Medan. Pada hasil wawancara dengan pak Reza dan selaku guru bimbingan dan konseling terdapat 6 orang siswa yang memiliki permasalahan dalam kreativitas belajar. Pada saat belajar siswa memiliki kemalasan belajar, tidak mengembangkan pemikirannya dengan membuat kreatif untuk membuang kebosanan pada pembelajaran dan faktor dari luar seperti keluarganya kurang mendukung padadiri mereka. Kemudian mengenai pelaksanaan layanan penguasaan konten ini yang terdapat pada bimbingan konseling secara bentuk klasik dan mengenai kreativitas belajar. Sebelumnya belum pernadilakukan secara efektif tetapi siswa lebih sering diberikan layananlayanan lainnya kecuali layanan penguasaan konten mengenai kretivitas belajar secara klasika. Dengan diberikan suatu saran atau arahan dari guru bimbingan dan konseling peneliti langsung diberikan arahan untuk melalukan konseling kepada beberapa siswa yang kurang mengembangkan kreativitas belajar.

\section{KESIMPULAN}

Berdasarkan hasil penelitian yang dapat diketahui bahwa penerapan layanan penguasaan konten untuk mengembangkan kreativitas belajar anak berbakat siswa kelas VIII SMP Muhammadiyah 07 Tahun Ajaran 2019/2020. Sudah berjalan dengan baik dan sesuai rencana. Pada pelaksanaan layanan penguasaan konten 6 siswa yang mengalami kekurangan megembangkan kreativitas belajarnya dan setelah melakukan layanan sudah memiliki perubahan yang diharapkan dan pada pelaksanaan layanan penguasaan konten terjadi peningkatan sangat meningkat . 


\section{DAFTAR PUSTAKA}

Abalie. 2017. Kreativitas dan Pembangunan Ekonomi Umat. Absolute Media.

Desyafni, H., Firman, dan Ifdil. 2014. Peningkatan Motivasi Siswa Dalam Menyelesaikan Tugas Melalui Layanan Penguasaan Konten. Konselor, 3(2) 34-40.

Fenti, H. 2014. Bimbingan dan Konseling. Rajawali Pers.

Ghufron Nur M, S. Risnawati Rini. 2017. Teori-Teori Psikologi. Ar- Ruzz Media.

Hurlock, E.B. 2016. Kreativitas Belajar. Yayasan Obor Indonesia

Kartadinata, S. 2015. Menguak Tabir Bimbingan dan Konseling sebagai Upaya Pedagogis. UPI Press.

Khabibah. 2016. Belajar Menagajar. Budi Utama.

Kurniawan. 2011. Melatih Mengembangkan Kreativitas Anak. Tangga.

Megaton. 2013. Bimbingan dan Konseling. UPI Press.

Natadwidjaja, K. 2015. Bimbingan dan Konseling. Remaja Rosdakarya.

Prayitno. 2015. Bimbingan dan Konseling di Sekolah dan Madrasah (Berbasis Integrasi). Raja Grafindo Prsada.

Prayitno. 2017. Dasar-dasar Konseling. Cipta Pustaka Media Perintis.

Prayitno. 2017. Konseling Profesional Yang Berhasil. Raja Grafindo Persada.

Rachawati, Y., dan Euiskurniati. 2012. Strategi Pengembangan Pada Anak-Anak TK. Prenada Media Grup.

Rantha E., dan Afda, 2018. Peningkatan Disiplin Dalam Menaati Tata Tertib Dengan Menggunakan Teknik Modelling Melalui Layanan Pengusaan Konten Di Smp 49 Jakarta Pada Siswa Kelas 8 Tahun Ajaran 2018-2019. Jurnal Selaras : Kajian Bimbingan dan Konseling serta Psikologi Pendidikan, 1(2), 81-95.

Ria, A., dan Thorik, A. 2019. Integrasi Pengembangan Kreativitas Anak Usia dini di TK Kanisius Sorowajan Yogyakarta. Jurnal Pendidikan Anak Usia Dini, 3(2), 294-302.

Semiawan, C. R. 2019. Kreativitas Keberbakatan. Indeks.

Sugiyono. 2016. Metode Penelitian Kombinasi (Mixed Methods). Alfabeta. 
Sukardi. 2008. Metodelogi Penelitian Pendidikan Kompetensi dan Praktiknya. Bumi Aksara.

Sund. 2012. Pribadi Kreativitas. Bintang WarliArtika

Tohirin. 2013. Metode Penelitian Kualitatif dalam Pendidikan Bimbingan dan Konseling. RajaGrafindo Persada.

Utami, M. 2016. Pengembangan Kreativitas Anak Berbakat. Rineka Cipta.

Winkel, W.S \& Hastuti, M. M. S. 2013. Bimbingan dan Konseling di Instuti Pendidikan. Media Abdi. 